\title{
Sedimentation Rate and Sediment Accumulation at the Estuary of Rokan River, Indonesia
}

\author{
Musrifin Galib and Rifardi* \\ Department of Marine Sciences, Faculty of Fishery and Marine Sciences, Riau University \\ Kampus Bina Widya Sp.Panam Pekanbaru-Riau-Indonesia
}

\begin{abstract}
The objective of the study was to analyse the sedimentation rate and sediment accumulation at the estuary of the Rokan River. Sediment samples were collected from 3 sampling points, i.e. Southern, Western and Northern of Berkey Island. The samples were then analysed using ${ }^{210} \mathrm{~Pb}$ radioisotope of the alpha spectrometer. The bottom of the Rokan River estuary is dominated by fine silt. It was recorded that sedimentation rate in Southern, Western, and Northern of Berkey Island were 0.3, 0.22 , and $0.28 \mathrm{~cm} /$ year, respectively. The accumulation of sediment in each station was as follows; $3.13,2.88$, and 3.42 ton/ha/year. The age of sediment in the Southern Berkey Island was 23,71 years at depth $14 \mathrm{~cm}$, Western Berkey Island was 64,26 years, and in Northern Berkey Island was 26,59 years. Sedimentation rate inside was higher than outside of the estuary. Higher sediment accumulation was noted at the outer part of the estuary compared to the inner part. The sediments found in the central part of the estuary are older than those inside and outside.
\end{abstract}

Keywords: sediment accumulation; sedimentation rate; radioisotope $210 \mathrm{~Pb}$;

\section{INTRODUCTION}

An estuary is part of the sea that protrude into the mainland and met with the estuary of the river (Kennish, 2010). The estuary of the Rokan River on the east coast of Sumatera borders the Strait of Malacca. Dense transport activities, intensive use of the area as ports, farms, residential areas, residential areas, industries, and government centres put great pressure on and affect the sustainability of resources in these waters.

Sedimentation process that occurs continuously on the estuary will inhibit the flow of rivers and raise the water surface in the upstream. In addition, this condition will also make fishing activities and production in Bagansiapiapi (a city next to Rokan River estuary) decline and large tonnage ships can only sail during flood tide (Rifardi et al., 2011).

The estuary of the Rokan River is well known for its nutrient abundance from the upper reaches of the river. Therefore, Bagansiapiapi was once the largest fish producer in Indonesia even number two in the world after Bergen Norway in the Dutch government era (the 1930s). At that time,
Bagansiapiapi port landed 300,000 tons of fish per year. However, fish production did not last until now. The fish products have decline since the 1970s (Setyawati, 2008). Reduced fish catch in Bagansiapiapi waters, is believed due to sedimentation effect. Sedimentation occurring in the estuary is caused by activities in watershed areas among (Lihawa and Sutikno, 2009).

Some coastal waters experience the silting process due to accumulation of erosion from the mainland. In some river, estuaries formed delta in a short time as the forerunner of the birth of new sedimentation islands. One example of the new sedimentation case is the formation of the estuary of Rokan River on the East coast of Sumatera Island. During the decades, in this region, new deltas were formed, and the shoreline moved into the sea. One of the newly emerging islands is thought to be the result of this sedimentation process being Berkey Island. The sedimentation process has changed the basic shape of the ecology of the waters around the estuary of the Rokan River (Rifardi et al., 2011). 
Sedimentation at the estuary of the Rokan River is influenced by sediment feeds from the Rokan River due to natural processes and artificial phenomena and sedimentation results due to the characteristics of the Malacca Straits currents and waves. Sediment characteristics, distribution of mean size dominated by fine sand class with poorly sorted grain uniformity. The tendency of sediment distribution in deep areas shows very fine skewed and shallow areas are occupied by very coarse skewed (Putra, 2015).

Determination of sediment age with natural radioisotopes ${ }^{210} \mathrm{~Pb}$ has been widely used both in lakes and in marine waters. Measurements of the specific activity of ${ }^{210} \mathrm{~Pb}$ in the coring sediment layer can determine the age of sediment up to about 150 years into the past. So, the determination of sediment age with ${ }^{210} \mathrm{~Pb}$ is suitable for use as a tool for studying changes and events in periods where human activity begins to impact on the environment with significant changes in the surrounding environment (Susiati et al., 2007).

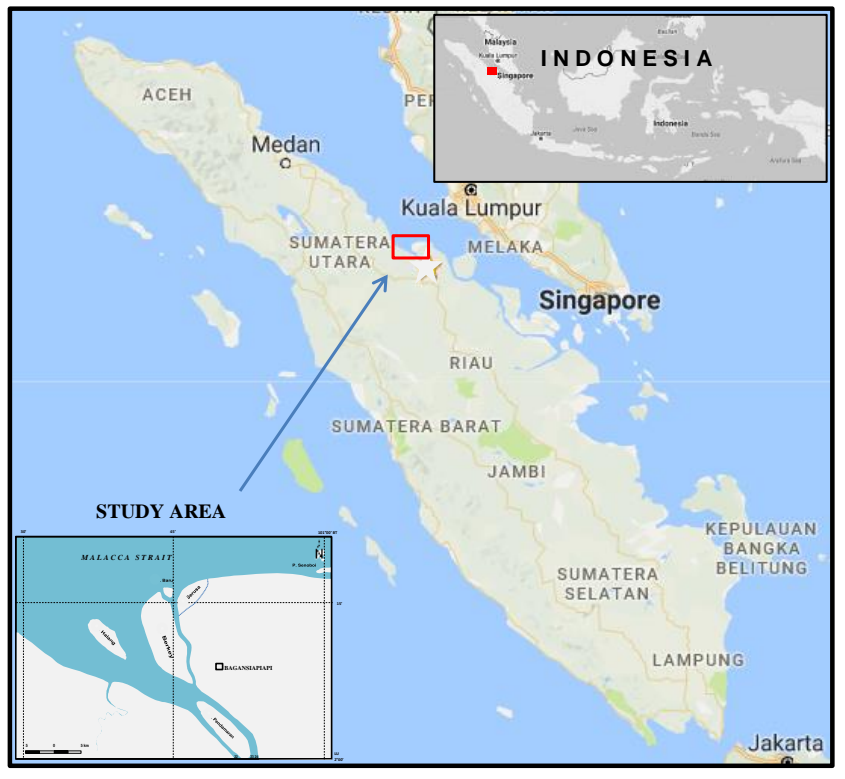

Figure 1. Index map of the study area

Radioisotopes ${ }^{210} \mathrm{~Pb}$ is one of ${ }^{238} \mathrm{U}$ decay, its presence in the sediments comes from the process: ${ }^{226} \mathrm{Ra}$ decays and ${ }^{222} \mathrm{Rn}$ gas is emitted into the air to form ${ }^{210} \mathrm{~Pb}$ excess (unsupported). Then down to the surface of the water and bind to the suspension particles then settles together to form a layer of sediment. The layers formed due to the decay of ${ }^{226} \mathrm{Ra}$ contained in the sediment through the equilibrium process and decay to ${ }^{210} \mathrm{~Pb}$ (supported) (Lubis et al., 2007).
The purpose of this study was to analyse sedimentation rate and sediment accumulation using ${ }^{210} \mathrm{~Pb}$ radioisotope method at Rokan River estuary (Figure 1). The study also estimated the age of the sediments and its distribution at the estuary.

\section{MATERIALS AND METHOD}

Sediment samples were collected from 24 stations at the estuary of the Rokan River in November 2016 (Figure 2). Global Positioning System (GPS) used to determine Station position. Sediment sampling using Grab Sampler. Sediment samples were analysed by grain size using graphical methods according to Folk and Ward (Rifardi, 2017). Sediment characteristics include mean size $(\mathrm{Mz} \varnothing)$, skewness $\left(\mathrm{Sk}_{\mathrm{i}}\right)$, coefficient sorting $\left(\mathrm{O}_{\mathrm{i}}\right)$ and kurtosis $(\mathrm{KG})$ also calculated.

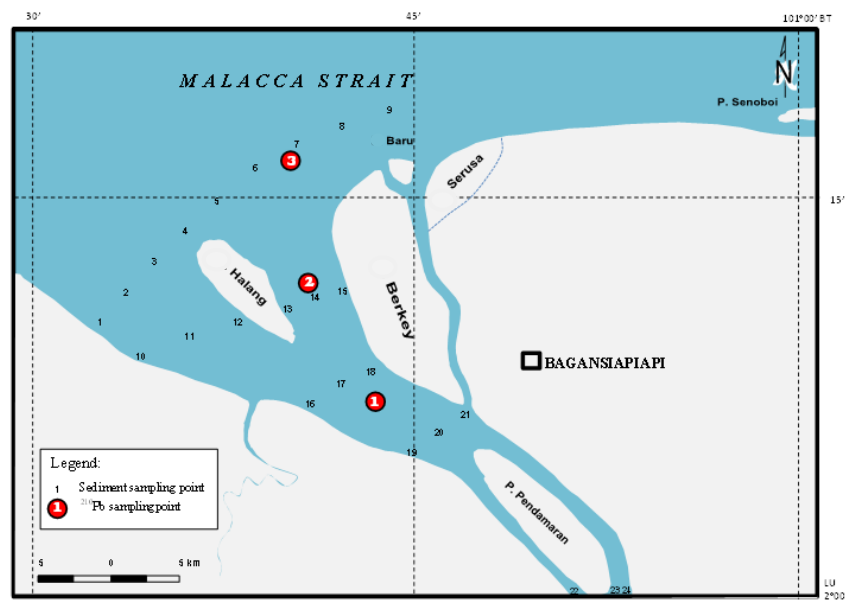

Figure 2. Map of Sediment and ${ }^{210} \mathrm{~Pb}$ sampling points

The sediment samples for the ${ }^{210} \mathrm{~Pb}$ analysis were collected from 3 sampling points, i.e. St.1u (Southern Berkey Island), St.2u (Western Berkey Island), and St.3u (Northern Berkey Island) using gravity core (Rifardi, 2011).

The sediment age and accumulation rate were determined using the Constant Rate of Supply (CRS) model (Lubis and Susiati., 2011). The calculated were as follows:

$$
\begin{aligned}
& \text { Ad }=\text { Aoe- } \lambda t \\
& t=1 / \lambda \cdot \ln (\text { Ao } / \text { Ad }) \\
& \lambda=\ln 2 / \mathrm{T} 1 / 2
\end{aligned}
$$

where:

$\mathrm{Ad}=$ unsupported ${ }^{210} \mathrm{~Pb}$ in core below depth

Ao $=$ unsupported ${ }^{210} \mathrm{~Pb}$ in core at depth

water interface 
$\lambda=$ decay constant ${ }^{210} \mathrm{~Pb}$

$\mathrm{T} 1 / 2=22.26$ years

$\mathrm{t}=$ time

The equation calculated the variation in sediment accumulation rate:

$$
\mathrm{r}=\lambda \mathrm{Ad} / \mathrm{Cd}
$$

where:

$\mathrm{Cd}=$ unsupported concentration of ${ }^{210} \mathrm{~Pb}$

\section{RESULT AND DISCUSSION}

A. Result

The results of grain size analysis of the 24 bottom sediment samples are shown in Table 1. The silt sediment fraction dominates the bottom of the estuary of the Rokan River. This

(4) type of silt sediment occupies almost the entire bottom of the estuary. Only one station has a sandy silt sediment type, St 6 located northern Halang Island. The type of sand sediments found in the upper reaches of the estuary was St. 22, 23 and St. 24. Those regions were located in the southern Pendamaran Island. Current velocity in this region reaches $1.13 \mathrm{~m} / \mathrm{sec}$, and low depth was only 1 meter.

Table 1. Results of mechanical analysis of the bottom surface sediments

\begin{tabular}{|c|c|c|c|c|}
\hline St & MeanSize $(M z \varnothing)$ & Skewness $\left(\mathrm{Sk}_{1} \phi\right)$ & Sorting $\left(\delta_{1} \varnothing\right)$ & Kurtosis $\left(\mathrm{K}_{\mathrm{G}}\right)$ \\
\hline 1. & 7.20 & -0.430 & 0.96 & 1.02 \\
\hline 2. & 6.77 & -0.823 & 1.44 & 9.15 \\
\hline 3. & 7.30 & -0.762 & 0.93 & 10.86 \\
\hline 4. & 5.57 & -0.898 & 2.22 & 2.19 \\
\hline 5. & 6.03 & -0.900 & 1.90 & 12.50 \\
\hline 6. & 5.23 & -0.905 & 2.44 & 0.51 \\
\hline 7. & 7.23 & -0.338 & 1.09 & 13.11 \\
\hline 8. & 7.23 & -0.694 & 0.92 & $7 \cdot 38$ \\
\hline 9. & 6.20 & -0.875 & 1.76 & 12.30 \\
\hline 10. & 7.20 & -0.443 & 0.90 & 10.86 \\
\hline 11. & 6.53 & -0.871 & 1.60 & 9.02 \\
\hline 12. & 7.27 & -0.583 & 0.80 & 6.56 \\
\hline 13. & 5.73 & -0.889 & 2.03 & 2.24 \\
\hline 14. & 7.27 & -0.597 & 0.73 & 5.87 \\
\hline 15 . & $7 \cdot 33$ & -0.146 & 0.32 & 2.19 \\
\hline 16. & 7.20 & -0.436 & 0.81 & 6.42 \\
\hline 17. & 6.77 & -0.831 & 1.30 & 11.89 \\
\hline 18. & 7.20 & -0.450 & 1.01 & 8.20 \\
\hline 19. & 6.17 & -0.890 & 1.77 & -12.09 \\
\hline 20. & 7.20 & -0.450 & 0.98 & 11.89 \\
\hline 21. & 5.43 & -0.900 & 2.29 & 0.69 \\
\hline 22. & 4.53 & 0.600 & 1.83 & 2.72 \\
\hline 23. & 4.60 & 0.500 & 1.86 & 0.56 \\
\hline 24. & 4.03 & 0.680 & 2.07 & 0.51 \\
\hline
\end{tabular}


Very fine sand was found in five stations: St 5, 6, 15, 16 and 21. The mean size (Mz) surface sediment pattern of the south of the estuary of Rokan River shows that the fine sand class dominates the adjacent sediments towards the Strait of Malacca, in contrast, the pattern of class distribution of very fine sands of sand tends to spread around the Berkey Strait (Figure 3).

The distribution of sediment type of Rokan River estuary was divided into three types of sediment, i.e. silt, sandy silt, and sand. The type of silt sediment spreads from the northern of Pendamaran Island reaches the estuary of the Rokan River in the Malacca Strait. The type of sandy silt sediment is found starting from the central region of the Pendamaran Strait 1 and 2 to the Northern of Pendamaran Island.

From the mean size of the sediment, it can see that type of silt in the estuary consists of classifications of coarse, medium, fine and very fine silt. The very fine silt dominated the bottom of these estuaries, almost half of the existing silt sediments (46\%). Coarse silt was only $12.5 \%$, the rest was medium silt and fine silt. Coarse silt was in the upper reaches of the estuary, the southern of Pendamaran Island on St 22, 23 and St 24 (Figure 3). The current velocity in this area was quite high at $1.04 \mathrm{~m} / \mathrm{sec}-\mathbf{1 . 3 2} \mathrm{m} / \mathrm{sec}$.
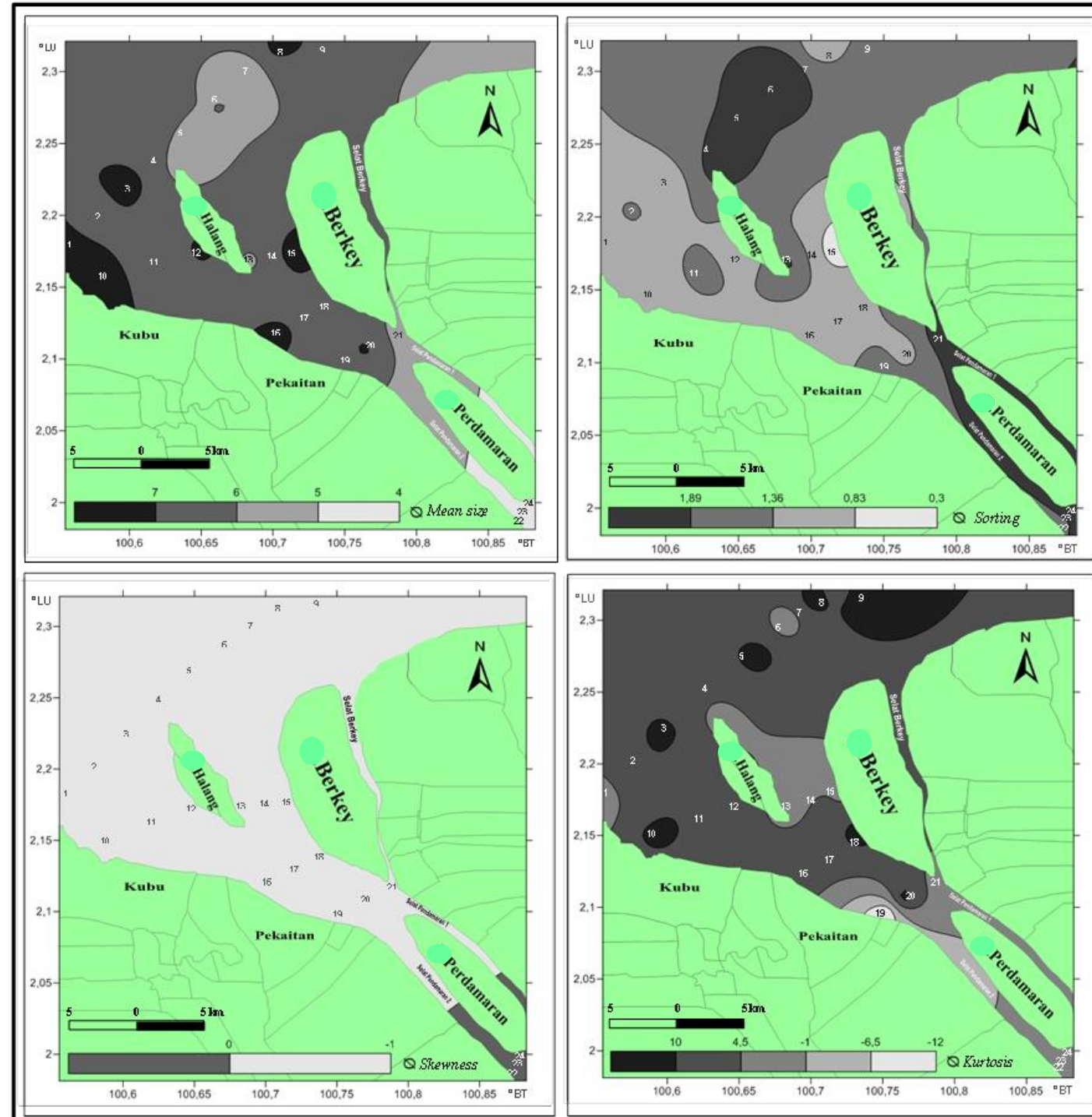

Figure 3. Distribution of Mean Size, Sorting, Skewness, and Kurtosis

The value of skewness (Table 1) shows that the pattern of sediment distribution to the left. This condition is reinforced with the position of the Rokan River estuary directly opposite the Malacca Strait there is oceanographic activity that was the currents and waves dominant. The value of sediment skewness at the estuary was only two that were very coarse 
skewed and very fine skewed classification. Almost entirely classified very coarse skewed.

The value of kurtosis showed that the peak of the sedimentary curve that spread in the estuary of the Rokan River was sharp. Spread over the estuary in the Malacca Strait then in the Western and Eastern of Halang Island. Then extremely leptokurtic spread in the Southwestern of Berkey Island to the South of Berkey Island on St 20. It was generally seen that the distribution of sediments with the leptokurtic classification, both extremely and very leptokurtic was dominated $75 \%$ of the bottom estuary. The rest were a classification of mesokurtic, platykurtic, and highly platykurtic sediments which, among other things, spread in the southern of Pendamaran Island on St 23 and St 24.

The average sedimentation rate in the southern of Berkey Island (St.1u) from 1931 - 2016 in 85 years was $0.31 \mathrm{~cm} / \mathrm{yr}$. The highest sedimentation rate occurs in 2013 at a depth of $o$ - $4 \mathrm{~cm}$, that is $1.51 \mathrm{~cm} /$ year. While the lowest sedimentation rate of $0.14 \mathrm{~cm} /$ year at a depth of $22 \mathrm{~cm}$ was estimated to be formed in 1960 (Table 2 and Figure 4).

Table 2. Sedimentation Rate, Accumulation, and Sediment Age Based on ${ }^{210} \mathrm{~Pb}$ Analysis (St.1u).

\begin{tabular}{|l|l|l|l|l|l|}
\hline No & Depth (cm) & $\begin{array}{l}\text { Sedimentation Rate } \\
(\mathrm{cm} / \mathrm{yr})\end{array}$ & $\begin{array}{l}\text { Accumulation } \\
(\mathrm{ton} / \mathrm{ha} / \mathrm{yr})\end{array}$ & Sediment Age (yrs) & $\begin{array}{l}\text { Estimated } \\
\text { Year }\end{array}$ \\
\hline 1 & 0 & 0.00 & 0.0 & 0.00 & 2016 \\
\hline 2 & 4 & 1.51 & 10.3 & 2.64 & 2013 \\
\hline 3 & 6 & 0.66 & 7.4 & 5.69 & 2010 \\
\hline 4 & 8 & 0.49 & 6.2 & 9.74 & 2006 \\
\hline 5 & 10 & 0,55 & 6.7 & 13.39 & 2003 \\
\hline 6 & 14 & 0.39 & 3.4 & 23.71 & 1992 \\
\hline 7 & 18 & 0.98 & 7.8 & 27.80 & 1988 \\
\hline 8 & 22 & 0.14 & 1.8 & 56.12 & 1960 \\
\hline 9 & 26 & 0.14 & 1.7 & 85.02 & 1931 \\
\hline
\end{tabular}

The accumulation of sediments from 1931 - 2016 in St.1u reached 266.42 tons and an average sediment accumulation rate of 3.13 tons/ha/yr. The highest sediment accumulation occurred in 2013 of $4 \mathrm{~cm}$ sediment depth which is 10.3 tons/ha/yr, while the lowest sediment accumulation in sediment depth 22 - $26 \mathrm{~cm}$ was estimated to be formed in 1931 that is 1.7 ton/ha/yr (Figure 4).

The results of the ${ }^{210} \mathrm{~Pb}$ radioisotope analysis for the estimated age of sediments in St.1u showed that sediments at $26 \mathrm{~cm}$ depth were estimated to be 85.02 years old and formed in 1931 (Figure 4).

The average sedimentation rate from 1952 - 2016 was 0.22 $\mathrm{cm} / \mathrm{yr}$. If the calculation of the sedimentation rate was based on the accumulation of sediment and total density (bulk density), the average sedimentation rate was $0.29 \mathrm{~cm} / \mathrm{yr}$. The lowest sedimentation rate in the western of Berkey Island (St.2u) occurred in 1987 at a depth of $6-8 \mathrm{~cm}$ sediments of only $0.17 \mathrm{~cm} /$ year. While the highest occurred in 2013 reached $1.41 \mathrm{~cm} / \mathrm{yr}$ in the depth of $0-2 \mathrm{~cm}$ (Table 3 and Figure $5)$.

The amount of sediment accumulation in Western of Berkey Island from 1952 - 2016 reached 185.10 tons with an accumulated average rate of 2.88 tons/ha/year. The highest sediment accumulation occurred in 2013, reaching 9.5 ton/ha/year in the depth of 0-2 cm. Meanwhile, the lowest sediment accumulation of only 2.0 ton/ha/year occurred in the 10 - $14 \mathrm{~cm}$ depth layer estimated to be formed in 1952 (Figure 5).

St.2u station located in the western of Berkey Island is estimated to have a 64.26-year sediment age at a depth of 14 cm and was estimated to be formed in 1952 (Figure 5).

The average sedimentation rate in the northern of Berkey Island (St.3u) from 1929 to 2016 in 87 years is $0.28 \mathrm{~cm} / \mathrm{yr}$. This average sedimentation rate is almost similar to the average sedimentation rate when referring to the accumulation of sediment and the total density of 0.27 
$\mathrm{cm} /$ year. Sedimentation rate, sediment accumulation and sediment age of St.3u can be seen in Table 4 .

The highest sedimentation rate occurred at a depth of $4-8$

$\mathrm{cm}$, which was estimated to be formed in 2003, that was 0.78 $\mathrm{cm} / \mathrm{yr}$. The lowest of $0.08 \mathrm{~cm} /$ year occurred at a depth of 20$22 \mathrm{~cm}$ estimated to have formed in 1949 (Figure 6).
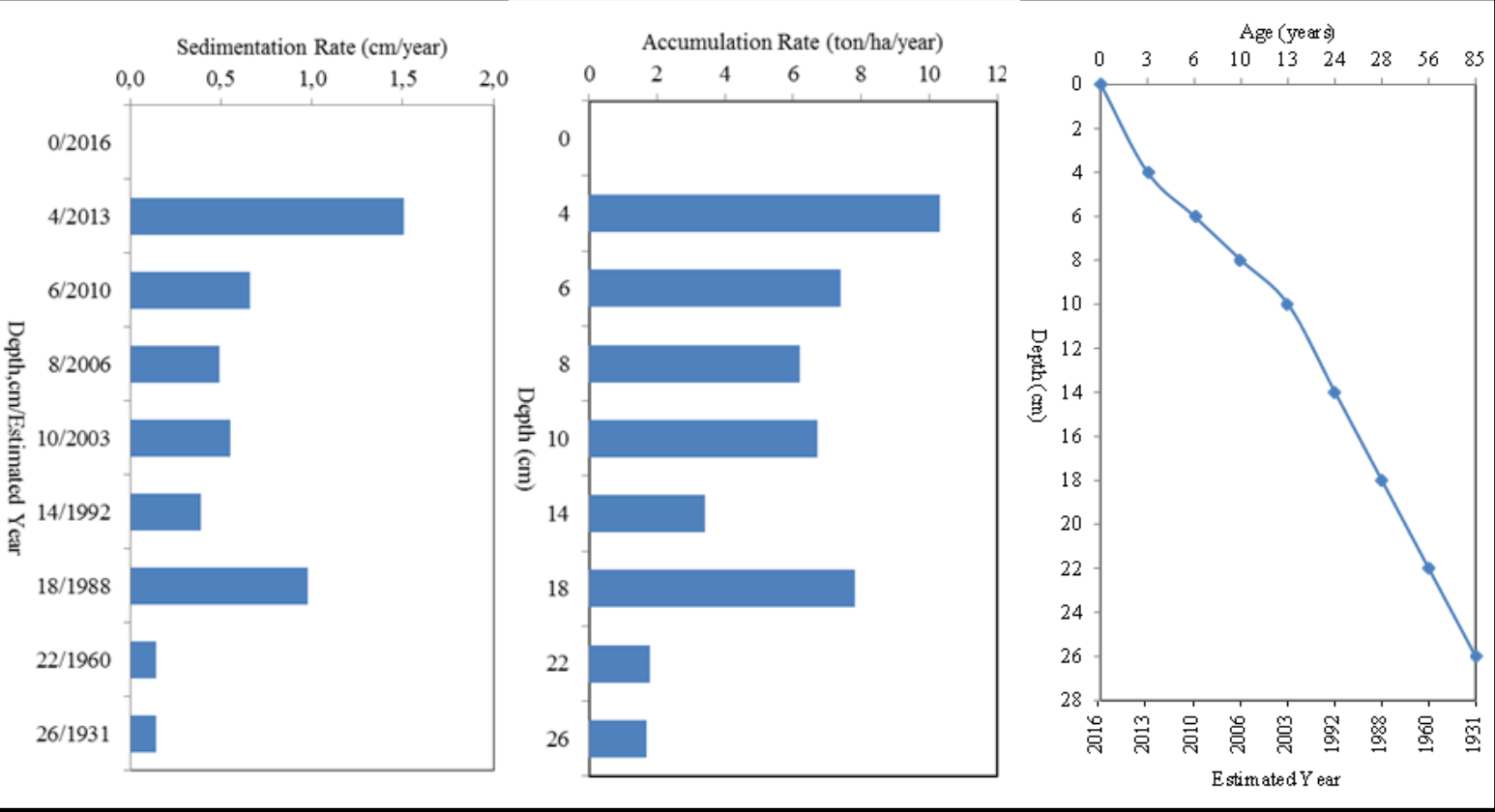

Figure 4. Sedimentation rate, Accumulation, and Sediment Age (St.1u)

Table 3. Sedimentation Rate, Accumulation, and Sediment Age Based on ${ }^{210} \mathrm{~Pb}$ Analysis (St.2u)

\begin{tabular}{|l|l|l|l|l|l|}
\hline No & $\begin{array}{l}\text { Depth } \\
(\mathrm{cm})\end{array}$ & $\begin{array}{l}\text { Sedimentation Rate } \\
(\mathrm{cm} / \mathrm{yr})\end{array}$ & $\begin{array}{l}\text { Accumulation } \\
(\text { ton/ha/yr) }\end{array}$ & Sediment Age (yrs) & Estimated Year \\
\hline 1 & 0 & 0.00 & 0.0 & 0.00 & 2016 \\
\hline 2 & 2 & 1.41 & 9.5 & 2.78 & 2013 \\
\hline 3 & 6 & 0.30 & 3.4 & 16.99 & 1999 \\
\hline 4 & 8 & 0.17 & 2.2 & 28.86 & 1987 \\
\hline 5 & 10 & 0.30 & 3.7 & 36.78 & 1979 \\
\hline 6 & 14 & 0.22 & 2.0 & 64.26 & 1952 \\
\hline
\end{tabular}




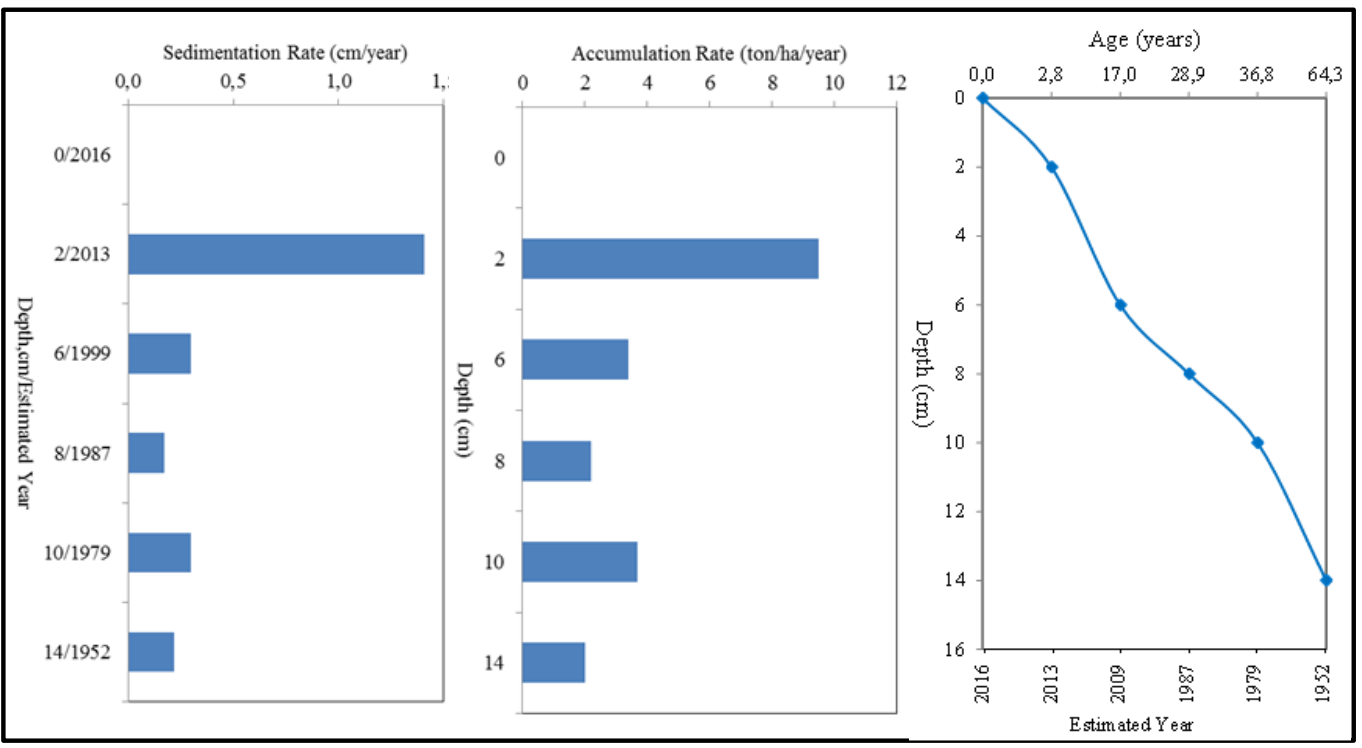

Figure 5. Sedimentation rate, Accumulation, and Sediment Age (St.2u)

Table 4. Sedimentation Rate, Accumulation, and Sediment Age Based on ${ }^{210} \mathrm{~Pb}$ Analysis (St.3u)

\begin{tabular}{|l|l|l|l|l|l|}
\hline No & Depth (cm) & $\begin{array}{l}\text { Sedimentation } \\
\text { Rate(cm/yr) }\end{array}$ & $\begin{array}{l}\text { Accumulation } \\
\text { (ton/ha/yr) }\end{array}$ & Sediment Age (yrs) & Estimated Year \\
\hline 1 & 0 & 0.00 & 0.0 & 0.00 & 2016 \\
\hline 2 & 2 & 0.60 & 10.9 & 3.32 & 2013 \\
\hline 3 & 4 & 0.41 & 5.7 & 8.16 & 2008 \\
\hline 4 & 8 & 0.78 & 6.7 & 13.30 & 2003 \\
\hline 5 & 12 & 0.45 & 6.9 & 22.18 & 1994 \\
\hline 6 & 16 & 045 & 3.3 & 31.00 & 1985 \\
\hline 7 & 20 & 0.36 & 3.8 & 42.23 & 1974 \\
\hline 8 & 22 & 0.08 & 1.3 & 67.04 & 1949 \\
\hline 9 & 24 & 0.10 & 1.7 & 87.02 & 1929 \\
\hline
\end{tabular}

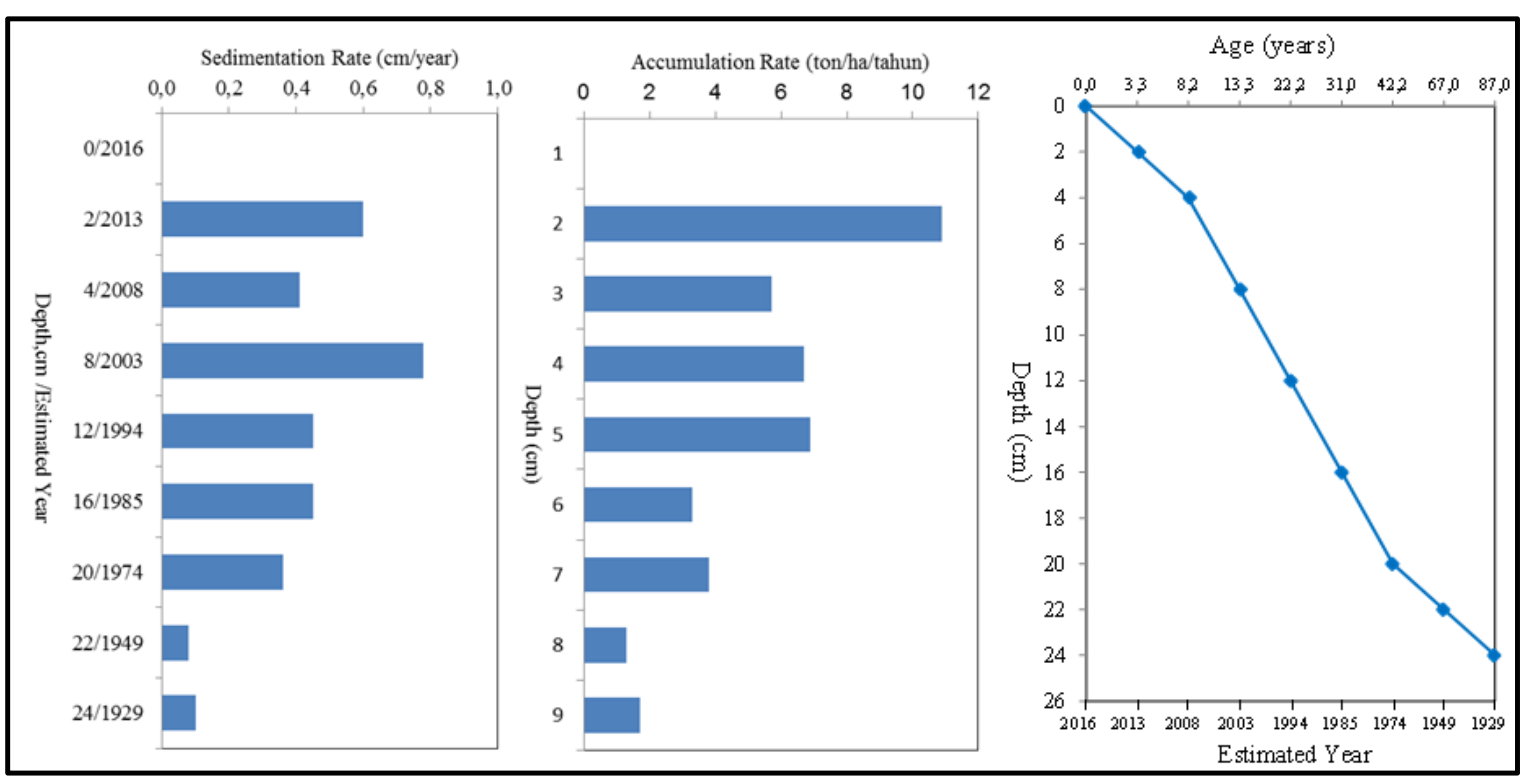

Figure 6. Sedimentation rate, Accumulation, and Sediment Age (St.3u) 
The amount of sediment accumulation from 1929 - 2016 at Station 3u (Northern Berkey Island) reached 297.49 tons with an average accumulation of 3.42 tons/ha/yr. The highest sediment accumulation occurred in 2013, which reached 10.9 tons/ha/yr in the depth of $0-2 \mathrm{~cm}$. The lowest sediment accumulation of 1.3 tons/ha/yr occurred at a depth of $20-22$ $\mathrm{cm}$, which was estimated to be formed in 1949 (Figure 6).

The results of ${ }^{210} \mathrm{~Pb}$ radioisotope analysis for determination of sediment age and sedimentation rate of St.3u located in the northern of Berkey Island showed that the age of sediment at 22-24 cm depth reached 87.02 years (Figure 6) and was estimated to be formed in 1929.

\section{B. Discussion}

The silt fraction in the silt sediment type at the upland estuary reaches $95.83 \%$, i.e. on St. 15 located on the western coast of Berkey Island. Kennish (2010) explains that the bottom waters of estuaries are mainly composed of clay, silt, sand, and organic matter. Clay and silt are dominant in the middle of the estuary and a rather sheltered part of the area. The sand and larger particles are concentrated in the estuary around the tidal area, in shallow waters and in open areas susceptible to drift. The general pattern of sedimentation in an estuary is the deposition of coarse sediments, both river and sea, and away from mixing zone, it is dominated by medium-size sediments.

The high current velocity in St. 22-24 cause the silt fraction is not possible for settling. Siegel et al. (2009) explain that for the silt fraction having a particle size of $0.002-0.063 \mathrm{~mm}$ will settle at a settling velocity of $0.006-5.0 \mathrm{~mm} / \mathrm{sec}$ (0.005 $\mathrm{m} / \mathrm{sec}$ ). At St. 22. the fraction of sand sediments reached $78.87 \%$. According to Rifardi et al. (2011) that the waters of Bagansiapiapi estuaria characterized by fine sand to very fine sand (Mz: 2.27 - 3.57 Ø). The distribution of mean size values indicates that fine sand dominated at the study area.

Fine silt dominated the estuary from Northern Pendamaran Island to the mouth estuary in Malacca Strait. However, in the western of Halang Island and Berkey Island, there was very fine silt in St 12 and St. 15. Likewise, in the Eastern part of Kubu, there are some very fine silts, namely St 1 and 10. In St 16 also found very fine silt. This indicates that the current strength to transport sediments was weak.
The medium silt is located in the central part of the Pendamaran Strait 1 and 2 to the North end of Pendamaran Island. To the south of these waters was found coarse silt up to the Southern Pendamaran Island. According to Kennish (2010). at the top of the estuary where the current velocity is relatively strong then the rough sediments that dominate.

The extent of sediment distribution with very coarse skewed indicates that in this region, there were influences of currents and waves. The negative skewness value was suspected to be the addition of coarse sediment particles above the fine sediment particles derived from current and wave activity. Rifardi (2008) explains that negative values are due to the excess of course materials from normal distributions and allegedly produced by the environment that is subjected to wave activity.

Moderately sorted classification is spreading in the Eastern part of Kubu and Pekaitan, western of Halang and Berkey Island. Distribution of poorly sorted spread in the estuary of the estuary towards the Malacca Strait, the northwestern of Halang and Northern Berkey Island. Then spread also to the southeastern of Halang and Southern Berkey Island. Rifardi (2017) explains that if a sediment deposition environment is poorly sorted, then the current and wave strength acting on the environment is unstable. Unstable because at any given moment, the power of currents and big waves but at other times the forces of currents and waves are weak.

The high sedimentation rate at St.1u in 2013 was closely related to the community activities that occur in the upper reaches of the Rokan River. These activities include land clearing and conversion from forest to plantation, causing surface erosion. The high sedimentation rate is closely related to the increasing amount of suspended sediment concentration (SSC) in the waters due to land conversion in the upper river. Dishut Provinsi Riau (2014) explains that from 1999 to 2013 or within 14 years, the number of land conversion or conversion of forest to plantation reached $15,258.2$ ha or on average each year land conversion function of 1,089.9 ha.

Erosion will increase the amount of suspended sediment concentration in the water. The high concentration of suspended sediments in the upper river will be carried by the current into the river estuary and then settle at the estuary of 
the river in areas with low current velocities such as the estuary of the Rokan River (Rifardi, 2011).

The high sedimentation rate in 2013 at St.2u is closely related to the community activities that occur in the upper reaches of the Rokan River. These activities include land clearing and conversion or conversion of land from forest to plantation, causing surface erosion. Dishut Provinsi Riau (2014) explained that the conversion of forest to plantations from 1985 to 2013 reached 153,109.4 ha. On average, every year land conversion from forest to plantation area is 6,379.6 ha within 24 years. Rifardi et al. (2011) explained that the rapid development of social and cultural communities on lands such as the opening of areas for settlements, industry, tourism, agriculture, land clearing, and other forms of land conversion resulted in the erosion of the surface layers of terrestrial sediments and will affect sedimentation processes in coastal and marine waters.

The high concentration of suspended sediments in the upper river will be carried by the current into the river estuary and then settle at the estuary of the river in areas with low current velocities such as the estuary of the Rokan River. According to Fathya (2012). there is a build-up of water masses when the tidal stream meets the river water going downstream. This allows sedimentation at the estuary of the river is greater than in the river. The terrestrial sediments will be transported through streams along the river until they reach the sea. Streams along the river as a result of this river carrying sediment and waste material coming from upstream and along river basins to be deposited at the estuary of the river.

The highest sedimentation rate in St.2u occurs in 2013, reaching $1.41 \mathrm{~cm} / \mathrm{yr}$ at a depth of o $-2 \mathrm{~cm}$ depth. Sa'adah et al. (2015) concluded that the average sedimentation rate in the Kapuas Kecil River is $1.17 \mathrm{~cm} / \mathrm{yr}$. The sedimentation rate is smaller than in Muara Jungkat (2.11 cm/year). According to Dishut Provinsi Riau (2014), that conversion of forest to plantation in Rokan Hilir District from 2000 - 2010 reached 9.773.4 ha or an average of 977.3 ha per year. High sedimentation may also be influenced by oceanographic factors as explained by Mulyanto (2010) that the tide will bring sediment from the sea into the estuary of the river to be deposited in the estuary and add high sediment in the area.
The amount of suspended sediments in the waters will be related to the erosion occurring in the upper river area. Erosion, especially erosion of the opening can occur, among others, due to the activity of land conversion or conversion of land from forest to plantation land. Khairunisa et al. (2013) explained that from 1988 to 2012, the amount of cliff erosion in the river basin Rokan River reached 1.767.0 ha. Sedimentation at Halang Island 63 ha, in Pendamaran Island covering an area of 1,253 ha and sedimentation at Berkey Island reached 4,398 ha.

\section{CONCLUSION}

The sedimentation rate is higher on inside estuary than outside. While the accumulation of sediment on the contrary, higher the outer of the estuary than in the estuary. The sediments found in the central of the estuary are older than those inside and outside the estuary. Bottom of the Rokan River estuary was dominated by fine silt. Tidal activity and wave dominantly influenced sediment distribution and sedimentation process.

\section{ACKNOWLEDGEMENT}

Infinite gratitude is presented to Dr Ali Arman Lubis, MSi. For the Laboratory facilities at National Nuclear Energy Agency of Indonesia (BATAN), Jakarta and helped analyse the sample Radioisotopes 210Pb. Appreciation is also conveyed to Ilham Ilahi, SPi., MSi. and Wahyu Wanda, SPi., who have assisted in the field and analysed samples in Pekanbaru. 


\section{REFERENCES}

Dishut Provinsi Riau 2014, Statistik Dinas Kehutanan Provinsi Riau Tahun 2013, Dinas Kehutanan Provinsi Riau, Pekanbaru.

Dishut Provinsi Riau 2015, Statistik Dinas Kehutanan Provinsi Riau Tahun 2014, Dinas Kehutanan Provinsi Riau, Pekanbaru.

Fathya, E.N. 2012, Kajian Sebaran Merkuri (Hg) terlarut di Sungai Kapuas, Kalimantan Barat, Program Studi Oseanografi, Institut Teknologi Bandung, Bandung.

Hariyanto, T., Krisna, T.C., Khomsin, Pribadi, C.B., and Anwar N. 2017, 'Development of Total Suspended Sediment Model using Landsat-8 OLI and In-situ Data at the Surabaya Coast, East Java, Indonesia', Indonesian Journal of Geography, vol. 49, no. 1, pp. 73 - 79.

Kennish, M.J. 2010, Ecology of Estuaries, vol. I, Physical and Chemical Aspects, CRC Press. Inc., First Edition 1986, Digital Edition 2010.

Kharunisa, W., Saraswati, R., Kusratmoko, E. 2013, Perubahan Alur Sungai di Muara Sungai Rokan Provinsi Riau Tahun 1988-2012, Departemen Geografi, Universitas Indonesia, Jakarta.

Lihawa, F. and Sutikno 2009, 'The Effect of Watershed Environmental Conditions and Landuse on Sediment Yield

in Alo-Pohu Watershed', Indonesian Journal of Geography, vol. 41, no. 2, pp. 103 - 122.

Lubis, A.A., Aliyanta, B. and Menry, Y. 2007, 'Estimation of Sediment Accumulation Rate in Jakarta Bay Using Natural Radionuclide Unsupported 210Pb', Indo. J. Chem., vol. 7, no. 3, pp. 309-313.

Mulyanto, H.R. 2010, Prinsip Rekayasa Pengendalian Muara dan Pantai, Graha Ilmu, Yogyakarta.

Putra, J.R. 2015, Analisis Sedimentasi di Muara Sungai Rokan Provinsi Riau, Thesis Program Pascasarjana, Program Studi Ilmu Kelautan Universitas Riau, Pekanbaru. Rifardi 2008, 'Distribution of Sediment, Benthic Foraminifera and Mercury in the South Yatsushiro Sea, Kyushu, Japan', Journal of Coastal Development, vol. 11, no. 3 .

Rifardi and Badrun, Y. 2017, 'Sandbar Formation in the Mesjid River Estuary, Rupat Strait, Riau Province, Indonesia', Indonesian Journal of Geography, vol. 49, no. 1 , pp. $65-72$.
Rifardi, Syahminan, Suwarni, R. Butar-Butar and Fidiatur N. 2015, Sedimentary Environments of the Dumai Coastal Waters on the East Coast of Central Sumatera Island, Indonesia, ASM Science Journal, vol. 9, no. 2, pp. 9-16.

Rifardi, Rufli, E., Rangga, A., Lubis, M., Roza, Y. and Sari P.N. 2011, 'Lingkungan Pengendapan Perairan Selatan Estuaria Bagansiapiapi dan Sekitarnya Pantai Timur Sumatera Indonesia', Jurnal Ilmu Lingkungan, vol. 5, no. 1.

Saadah, N., Subardjo, P., Atmodjo, W. and Ismail, M.F.A. 2015, 'Laju Sedimen Menggunakan Metode Isotop 210Pb di Muara Jungkat Pontianak Kalimantan Barat', Jurnal Oseanografi, vol. 4, no. 1.

Setyawati, S. 2008, Pasang Surut Industri Perikanan Bagansiapiapi 1898-1936, Thesis Program Pascasarjana Universitas Indonesia, Jakarta.

Siegel, E., Scettini, C.A.F., Klein, A.H.F. and Toldo Jr., E.E. 2009, 'Hydrodynamics and Suspended Sediment Transport in the Camboriu Estuary - Brazil: Pre Jetty Conditions', Brazilian Journal of Oceanography, vol. 57, no. 2.

Sumining and Sukirno 2006, Laju Sedimentasi dan Akumulasi Massa Sedimen Pantai Surabaya, Pusat Teknologi Akseleralor dan Proses Bahan-BATAN, Yogyakarta.

Susiati, H., Lubis, A.A., Yarianto, S.B.S., Fepriadi, Sarmin 2007, 'Aplikasi Teknik Nuklir Untuk Studi Geokronologi Sedimen di Perairan Pantai Lokasi Tapak PLTN Lemahabang, Semenanjung Muria, in Prosiding Seminar Nasional Teknologi Pengolahan Limbah VI, Pusat Teknologi Limbah Radioaktif-BATAN, Pusat Penelitian Ilmu Pengetahuan dan Teknologi-RISTE, Jakarta. 